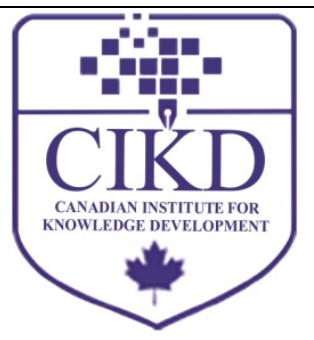

\title{
Leadership Styles of Managers from the Perspective of Gender
}

\author{
Lucia Zbihlejová $^{1^{*}}$, Miroslav Frankovský ${ }^{2}$ Zuzana Birknerová2 \\ ${ }^{1}$ Department of Intercultural Communication, Faculty of Management, University of Prešov in Prešov, Slovakia \\ ${ }^{2}$ Department of Managerial Psychology, Faculty of Management, University of Prešov in Prešov, Slovakia
}

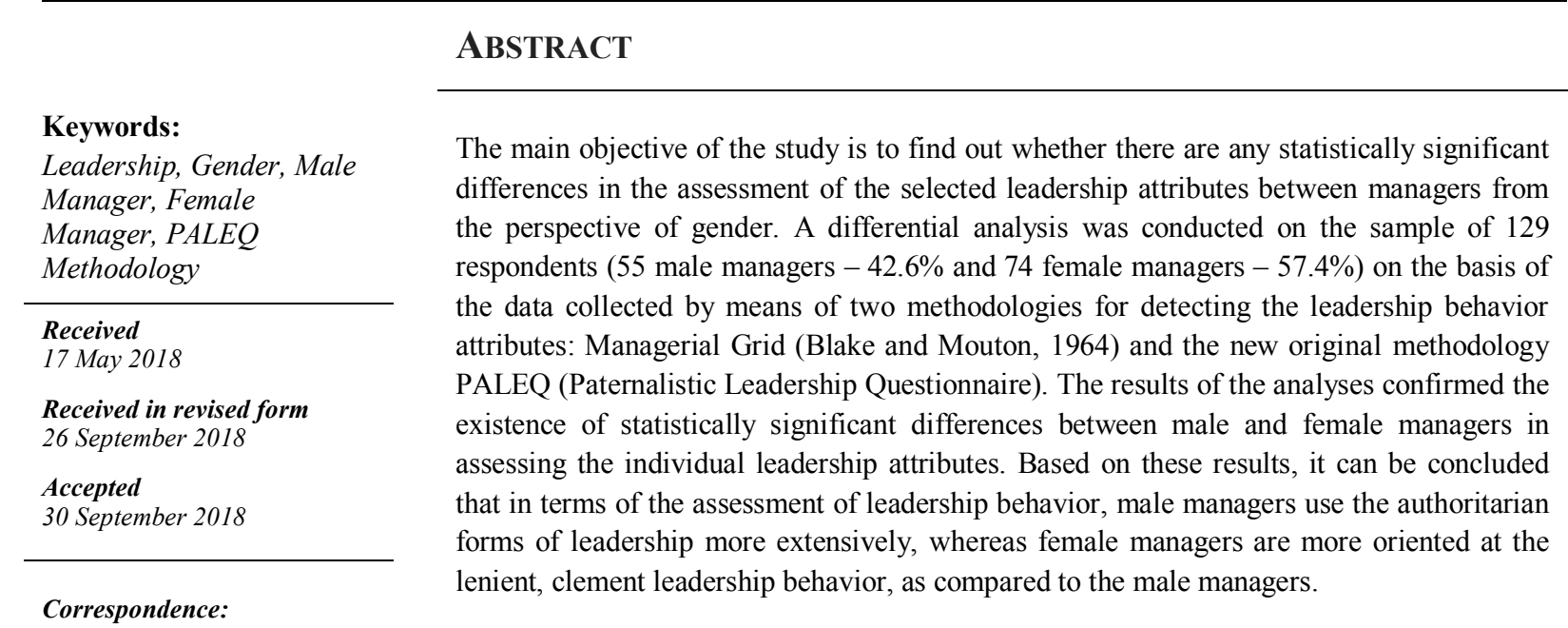

lucia.zbihlejova@unipo.sk

(C)AIMI Journals

Leaders, leadership, and the innovative nature of human resource management are some of the decisive factors in the competitive advantage (Lufthans, Hodgetts, \& Lufthans, 1997). The form and use of leadership styles play a significant role within the rich mosaic of human resource management. Rose and Kumar (2006) point out that implementation of the right practices in human resource management, leadership, and alignment of these practices with the company's business strategy, as well as the current situation requirements, significantly 
influence the performance of the organization as a whole. Lipiec (2001) adds that the companies, which aspire to be market leaders, must also have capable leaders in their portfolio.

Managers are expected to be leaders and decision makers in the context of both the day-today and the strategic solutions that, for instance, direct the company's further development. Drucker (2001) claims that this position of leaders is compounded by the fact that the current economic environment is characterized by an unprecedented turbulence and a staggering flow of change. The chance to survive is given only to those organizations the managers/leaders of which love changes and see not damnation, but an opportunity in them (Peters and Waterman, 1982).

The literature (e.g. Lelková \& Lorincová, 2017; Štefko, Fedorko, \& Bačík, 2015) contains broad discussions on who is a manager, who is a leader, and whether they are two individual personalities or a common label for a single personality. The objective of the proposed paper is not to judge or seek the truth about this matter but to provide an insight into leadership styles in terms of comparison of these styles between male and female managers. The main objective of the report is thus to detect whether there are any statistically significant differences in the assessment of the selected leadership styles between these respondent groups. At the same time, the identification and specification of leadership styles can be discussed in the context of prediction of behavior of managers, selection of people for managerial positions, preparation and training of managers.

\section{Leadership and Gender}

In past few years, there has been an increasing interest in examining leadership styles, which can be defined as sets of behaviors by which leaders influence their subordinates (Antonakis, Cianciolo, Sternberg, 2004; Bass \&Riggio, 2006). According to the concepts examined and provided by the literature so far, it can be concluded that there are four main groups of the leadership styles theories, namely the theories based on personality traits (e.g. Derue, Nahrgang, Wellman,\& Humphrey, 2011; Gardner, 1989; Zaccaro, Kemp,\& Bader, 2004), behavioral leadership theories (e.g. Blake \& Mouton, 1964; Goleman, 2000; Pellegrini Scandura, \& Jayaraman2007), situational leadership theories (e.g. Hersey, Blanchard and Johnson, 1996; Blanchard, 2008) and transformational leadership theories (e.g. Bass \& Riggio, 2006; Marshall, 2010).

In more recent studies, researchers (e.g. Dauber \& Tavernier, 2011; Brown \& Trevino, 2006; Einarsen,Aasland, \& Skogstad, 2007; Ferris et al., 2007; Schillig, 2008; Wijewardena, Samaratunge,\& Härtel, 2014), who try to deviate from this leadership typology, claim that it is important to distinguish between the positive and the negative (or ineffective) leadership approaches to subordinates and examine the impact a specific behavior has on the employees/subordinates/followers.

With regard to gender differences in the use of particular leadership styles, the studies are varied (Eagly \& Johnson 1990; Rosener 1990; van Engen \& Willemsen 2002). According to the results revealed by the research studies of several authors (Angst, Gamma, Gastpar, \&Tylee, 2002; Ashmore, Del Boca, \&Wohlers, 1986; Mckinsey \& Compony, 2009), typical male leaders accentuate achievement of organizational goals, while typical women leaders emphasize people and relationships. Rosener (1990) has found out that men tend to use force 
that comes from formal authority and their status within the organization more often than women. Nielsen and Huse (2010) add that the leadership styles vary between the genders in accordance with the particular tasks and situations. Yukl (2002) states that there is no gender difference in the efficiency of managers, but there are gender differences in certain forms of their behavior.

The following research study is, therefore, aimed at detecting the possible differences in the perception and usage of the particular leadership styles by managers according to their gender. Methodologically, it presents verification of the PALEQ - Paternalistic Leadership Questionnaire in the context of analyzing the differences in assessment of the attributes of leadership behavior between the male and female managers.

\section{The Study}

The objective of the presented research is to enrich the field of knowledge related to leadership and leadership behavior through development of a new methodology for assessment of the selected leadership attributes, as well as to detect whether there are any statistically significant differences in the assessment of the selected leadership styles between male and female managers.

\section{Sample}

The research file consisted of 129 respondents, 55 (42.6\%) of which were male managers and 74(57.4\%) were female managers, aged between 19 and 54 years $(M=29$ years, $S D=$ 8.601 years). One hundred and three managers $(79.8 \%)$ were from the private economic sector and 26 managers $(20.2 \%)$ were from the public sector.

\section{Methods}

Two methodologies were used to conduct the present research. They are described in the following part of the paper.

\section{PALEQ}

The original methodology labeled as PALEQ - Paternalistic Leadership Questionnaire was inspired by the theory of paternalistic leadership as such. Item formulation was based on the theory by Farh and Cheng (2000), who describe three attributes of paternalistic behavior of a leader, i.e. authoritarian behavior, benevolent behavior, and moral behavior. The original PALEQ contains 30 items relating to the leadership behavior. Respondents are to imagine themselves in a role of a manager/leader and evaluate their own possible behavior on a 6-point Likert scale, where $1=$ absolutely disagree, and $6=$ absolutely agree. The methodology enables identification of three attributes of leadership behavior:

- Authoritarianism - leader exhibits an absolute authority, power and control over subordinates and requires their unquestionable obedience, respect, and rule following ( $\alpha$ $=.75)$,

- Clemency - leader demonstrates individual, holistic and complex care for their subordinates and their subjective well-being $(\alpha=.85)$,

- Morality - leader demonstrates excellent personal qualities, integrity, self-discipline, role-modeling, and unselfishness $(\alpha=.73)$. 
The extracted factors (leadership attributes) explain $40.3 \%$ of variance.

\section{MG - Managerial Grid}

Managerial Grid (Blake \& Mouton, 1964) is a scheme used to evaluate leadership styles. It consists of two main dimensions (axes):

- Concern for production (x-axis)

- Concern for people (y-axis)

Each dimension has nine levels according to which it is possible to identify five typical leadership styles, namely (see Figure 1):

- $\quad 1.1=$ Impoverished/Indifferent style (low management/direction and low requirements for performance and task fulfillment);

- $\quad 1.9$ = Country club/Accommodating style (high orientation at people and interpersonal relationships, low orientation at task fulfillment and performance);

- 5.5 = Middle-of-the-road/Status quo style (middle-level orientation at relationships, satisfactory task fulfillment and performance);

- 9.1 = Produce or perish/Dictatorial style (low people-orientation, high orientation at performance and task fulfillment);

- $\quad 9.9=$ Team/Sound style (highest orientation at people and interpersonal relationships, as well as performance and task fulfillment).

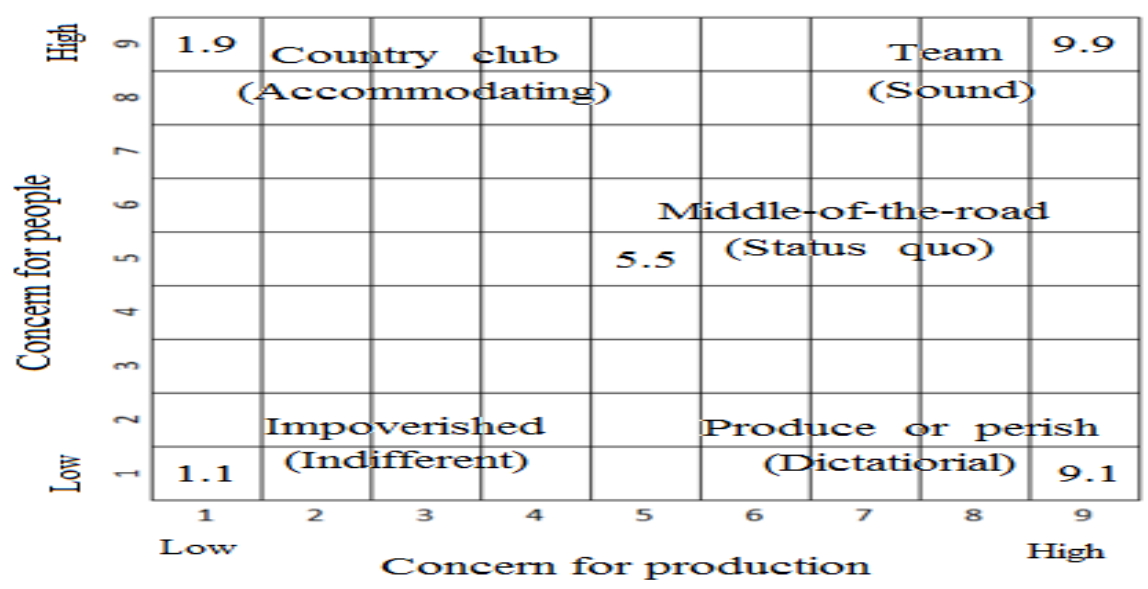

Figure 1. Managerial Grid (Blake \& Mouton, 1964)

This questionnaire, through which it is possible to detect the aforementioned leadership styles, consists of 18 items evaluated on a 6-point Likert scale, where $0=$ never, and $5=$ always. In practice, the Managerial Grid is used, for example, in crisis management, where the Concern for people has often a decreasing tendency and the Concern for production rapidly increases.

\section{Results}

The content validity of PALEQ was detected in relation to the standard methodology MG = Managerial Grid by Blake and Mouton (1964) and the factor inter-correlations are presented in Table 1. 
Table 1

Inter-correlations of the Leadership Factors of $M G$ and PALEQ

\begin{tabular}{llccc}
\hline & & Clemency & Morality & Authoritarianism \\
Concern for people & $\mathrm{r}$ & .53 & .34 & .13 \\
& $\mathrm{p}$ & .001 & .001 & .001 \\
Concern for production & $\mathrm{r}$ & .42 & .33 & .16 \\
& $\mathrm{p}$ & .001 & .001 & .001 \\
\hline
\end{tabular}

The Principal Component analysis with Varimax rotation enabled extraction of three factors identifying and specifying the individual leadership styles of managers (Table 2).

Table 2

Factor Specification of PALEQ

\begin{tabular}{lcl}
\hline Factors & No. Of items & $\begin{array}{l}\text { Description } \\
\text { Demonstration of the individual, holistic interest of the leader in the work and well- } \\
\text { being of the subordinates. }\end{array}$ \\
11 & 7 & $\begin{array}{l}\text { Behavior by which the leader exhibits excellent moral character and integrity by acting } \\
\text { unselfishly and as a role-model leader } \\
\text { Morality }\end{array} 12 \quad \begin{array}{l}\text { Behavior by which the leader promotes strong authority and control over subordinates, } \\
\text { from whom s/he requires obedience, observance of the rules, and respect. }\end{array}$ \\
Authoritarianism & 12 &
\end{tabular}

Differences in assessment of the leadership behavior attributes between male and the female managers were analyzed by means of t-tests for two independent selections in the statistical software SPSS 20. The acquired results confirmed the existence of statistically significant differences between the managers in terms of their gender in the assessment of the leadership factors of the methodologies MG and PALEQ (Table 3, Figure 2).

Table3

Comparisons of the PALEQ and MG Factor Assessments between Male and Female Managers

\begin{tabular}{|c|c|c|c|c|}
\hline PALEQ & Gender & $M$ & $t$ & $p$ \\
\hline \multirow[t]{2}{*}{ Clemency } & Male manager & 4.41 & -3.48 & .001 \\
\hline & Female manager & 4.69 & & \\
\hline \multirow[t]{2}{*}{ Morality } & Male manager & 4.35 & -1.15 & .25 \\
\hline & Female manager & 4.47 & & \\
\hline \multirow[t]{2}{*}{ Authoritarianism } & Male manager & 4.14 & 3.69 & .001 \\
\hline & Female manager & 3.09 & & \\
\hline $\mathrm{MG}$ & Gender & $M$ & $t$ & $p$ \\
\hline \multirow[t]{2}{*}{ Concern for people } & Male manager & 3.48 & -.37 & .70 \\
\hline & Female manager & 3.51 & & \\
\hline \multirow[t]{2}{*}{ Concern for production } & Male manager & 3.46 & -.56 & .57 \\
\hline & Female manager & 3.41 & & \\
\hline
\end{tabular}

The results of the analysis confirmed the existence of statistically significant differences between male and female managers in assessing the individual leadership attributes. Based on these results, it can be concluded that in terms of the assessment of leadership behavior, male managers use the authoritarian forms of leadership more extensively, whereas female managers 
are more oriented at the lenient, clement leadership behavior, as compared to the male managers.

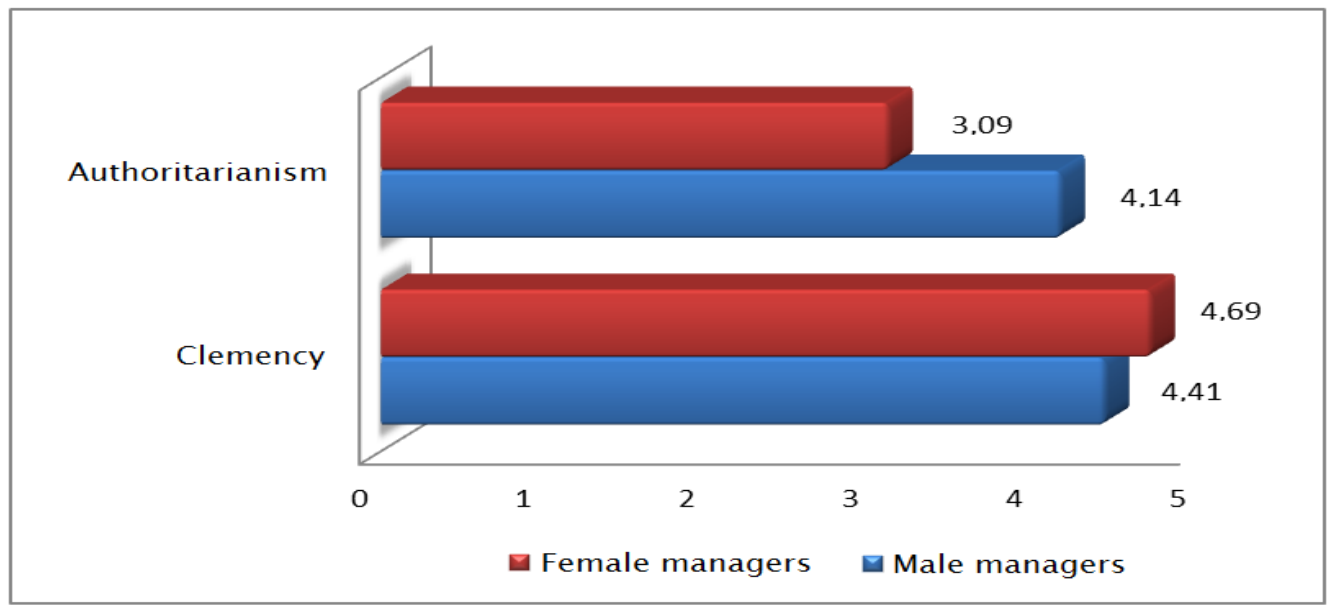

Figure 2. Assessment of the PALEQ methodology by male and female managers

The results of the analysis confirmed the existence of statistically significant differences between male and female managers in assessing the individual leadership attributes. While men scored higher in the PALEQ factor Authoritarianism, women achieved higher scores in the PALEQ factor Clemency.

It should be noted that the assessment of Clemency as well as Authoritarianism by both male and female managers are on the same (agreement) part of the scale used. Therefore, the identified differences are only within the extent to which the respondents agree with the given leadership attributes. Contrarily, assessment of Authoritarianism by male and female managers was on the opposite sides of the scale - male managers agreed with this leadership style, whereas female managers expressed disagreement with this form of leadership.

\section{Discussion and Conclusion}

The results obtained confirmed the existence of statistically significant differences between male and female managers in assessing the leadership factors of the leadership style measurement methodologies, particularly within the original PALEQ methodology.Based on these results, it can be concluded that in terms of the assessment of leadership behavior, male managers use the authoritarian forms of leadership more extensively, whereas female managers are more oriented at the lenient, clement leadership behavior, as compared to the male managers. In evaluation of the MG factors Concern for people and Concern for production no statistically significant gender-based differences were detected, which deviates from the results of the research studies by authors presented in the literature review.

In this context, Rosener (1990) also found out that men tend to use the power that comes from formal authority and their status within the organization more often than women. According to this author, the preferred style of men's leadership is through command and control, whereas women prefer to work interactively, share power and information. Jamieson (1995) describes a situation called "double bind ", where a female manager has no chance to succeed regardless of how well she performs, i.e. female managers should behave as 
authoritatively and strictly as men in order to be taken seriously. Eagly and Johnson (1990)have revealed in their research that women tend to show more democratic or participatory styles of leadership and somewhat less direct or autocratic styles than their male counterparts.

Another view on this matter is presented by Nielsen and Huse (2010), who claim that leadership styles vary between genders for specific tasks and situations, and that women and men do not differ in their ability to perform operational tasks but rather bring different perspectives in the strategic decision-making through an increased sensitivity towards others. Yukl (2002) concludes that there is no gender difference in the efficiency of managers, but there are gender differences in certain forms of their behavior.

Finally, it should be pointed out that the original PALEQ methodology can be applied in the context of several processes that are related to the management of people and in this context also with the managerial practice. Specifically, in the area of managerial work, it is possible to specify the use of this methodology in terms of selection of personnel for managerial positions, their further education and training, and preparation of operational and strategic materials in the field of management of employees.

\section{Acknowledgements}

This research was supported by the grant project VEGA 1/0909/16 (Research of determinants of decision-making in the business management and sales management, taking into account the personal and psychological aspects of trading, and analysis of the possible implications in neuromarketing).

\section{References}

Angst, J., Gamma, A., Gastpar, M.,\& Tylee, A. (2002).Gender differences in depression: Epidemiological findings from the European DEPRES-I and II studies. European Archives of Psychology and Clinical Neuroscience, 252, 201-209.

Antonakis, J., Cianciolo, A. T.,\&Sternberg, R. J. (2004).The nature of leadership. Thousand Oaks, CA: Sage Publications.

Ashmore, R. D., Del Boca, F.,\& Wohlers, A. (1986).Gender stereotypes. In R. D. Ashmore, \& F. Del Boca (Eds.),The Social Psychology of Female-Male Relations: A Critical Analysis of Central Concepts (pp. 69-119). New York: Academic Press.

Bass, B. M.,\& Riggio, R. E. (2006).Transformational leadership. 2nd ed. Mahwah, NJ: Lawrence Erlbaum.

Blake, R.,\& Mouton, J. (1964). The managerial grid: The key to leadership excellence. Houston: Gulf Publishing Co.

Blanchard, K. (2008). Situational leadership. Leadership Excellence, 25(5), 19.

Brown, M. E.,\& Trevino, L. K. (2006) Ethical leadership: A review and future directions. The Leadership Quarterly, 17, 595616.

Dauber, D.,\& Tavernier, A. (2011). Coping with ineffective leadership. IACCM 2011, June, 29 - July 1, Ruse: Bulgaria. Retrieved from: https://www.wu.ac.at/fileadmin/wu/o/iaccm/Abstracts/2011_Dauber_Tavernier_Ineffective_Leadership.pdf [Accessed 5 May 2015].

Derue, D. S., Nahrgang, J. D., Wellman, N. E. D., \& Humphrey, S. E. (2011). Trait and behavioral theories of leadership: An integration and meta-analytic test of their relative validity. Personnel Psychology, 4(1), 7-52.

Drucker, P. F. (2001).Management Challenges for the 21st Century. New York: Harper Business.

Eagly, A. H.,\& Johnson, B. (1990).Gender and leadership style: A meta-analysis. Psychological Bulletin, 108, $233-256$.

Einarsen, S., Aasland, M. S.,\& Skogstad, A. (2007). Destructive leadership behavior: A definition and conceptual model. The Leadership Quarterly, 18, 207-216.

Farh, J. L.,\& Cheng, B. S. (2000). A cultural analysis of paternalistic leadership in Chinese organizations. In: J. T. Li, A. S. Tsui, \&E. Weldon (Eds.),Management and Organizations in the Chinese Context (pp. 94-127). London: Macmillan. 
Ferris, G. R., Zinko, R., Brouer, R. L., Buckley, M. R., \& Harvey, M. G. (2007). Strategic bullying as a supplementary, balanced perspective on destructive leadership. The Leadership Quarterly, 18, 195-206.

Gardner, J. (1989).On leadership. New York: Free Press.

Goleman, D. (2000). Leadership that gets results. Harvard Business Review, 78(2), 78-90.

Hersey, P., Blanchard, K. H.,\& Johnson, D. E. (1996).Management of organizational behavior: Utilizing human resources. 7th ed. Upper Saddle River, NJ: Prentice-Hall.

Jamieson, K. H. (1995).Beyond the double bind: Women and leadership. New York: Oxford University Press.

Lelková, A.,\& Lorincová, T. (2017). Prediction of manipulation as a core part of social intelligence through selected personality traits in the context of business area. International Journal of Organizational Leadership, 6(1), $102-108$.

Lipiec, J. (2001) Human resources management perspective at the turn of the century. Public Personal Management, 30(2), $137-146$.

Lufthans, F., Hodgetts, R.,\& Lufthans, B. C. (1997). Human resources. the role of HRM in sustaining competitive advantage. National Productivity Review, 17(1), 73-92.

Marshall, E. (2010).Transformational leadership in nursing: From Expert clinician to influential leader.New York: Springer Publishing Company.

Mckinsey \& Compony. (2009). Women leaders: A competitive edge in and after the crisis. Retrieved from: https://www.mckinsey.de/files/women_matter_3_brochure.pdf [Accessed 5 May 2017].

Nielsen, S.,\& Huse, M. (2010) The contribution of women on boards of directions: Going beyond the surface. corporate governance.An International Review, 18(2), 136-148.

Pellegrini, E. K., Scandura, T. A.,\& Jayaraman, V. (2007). Generalizability of the paternalistic leadership concept: A crosscultural investigation. working paper, St. Louis: University of Missouri-St. Louis.

Peters, T. J.,\& Waterman, R. H. (1982). In search of excellence: Lessons from America's best-run companies. New York: Harper \& Row.

Rose, R. C.,\& Kumar, N. (2006). The influence of organizational and human resource management strategies on performance. Performance Improvement, 45(4), 18-24.

Rosener, J. B. (1990). Ways women lead: The command-and-control leadership style associated with men is not the only way to succeed. Harvard Business Review, 119-125.

Schillig, J. (2008). From ineffectiveness to destruction: A qualitative study on the meaning of negative leadership. Leadership and Organizational Development Journal, 5(1), 102-108.

Štefko, R., Fedorko, R.,\& Bačík, R. (2015). The role of e-marketing tools in constructing the image of a higher education institution. Procedia Social and Behavioral Sciences, 175, 431-438.

van Engen, M.,\& Willemsen, T. M. (2002).Gender and leadership style: A review of the past decade. Tilburg, The Netherlands: Tilburg University.

Wijewardena, N., Samaratunge, R.,\& Härtel, C. (2014). Creating better employees through positive leadership behavior in the public sector. International Journal of Public Administration, 37(5), 288-298.

Yukl, G. (2002).Leadership in organizations. Upper Saddle River: Prentice Hall.

Zaccaro, S. J., Kemp, C.,\& Bader, P. (2004).Leader traits and attributes. The nature of leadership. Thousand Oaks, CA, US: Sage Publications, Inc. 